\title{
APRESENTAÇÃO DO II ENCONTRO NACIONAL DE TRADUTORES ${ }^{1}$
}

\section{Maria Candida Bordenave}

Faz uma década que se realizou com grande êxito, na PUC do Rio de Janeiro, o I Encontro Nacional de Tradutores. Desde então, não cessaram de ser ouvidas vozes saudosistas relembrando o sucesso, como também palavras de estímulo para que se repetisse o evento. Hoje, o Curso de Tradução do Departamento de Letras, sentindo que suas atividades acadêmicas encontram-se bem estruturadas, seus cursos e estágios solidamente organizados, sua prática e teoria sadiamente integradas e fundamentadas, decide, mais uma vez, ultrapassar suas fronteiras e reunir, no espaço da Universidade, em amplo debate, todos aqueles envolvidos na atividade tradutória: professores, pesquisadores e estudantes, tradutores e editores, intelectuais, bem como representantes de instituições usuárias de tradução.

Foi, então, pensando no evento de abril de 1975, tão significativo e bemsucedido, e pensando também no nosso presente, como formadores de profissionais de tradução e portanto profundamente participantes da glória e do drama desses profissionais, que nós, da comissão organizadora, decidimos dar esse salto em busca da nossa realidade e do nosso lugar na história da cultura nacional.

Três ideias nos inspiraram e nos impulsionaram para a realização deste Encontro. A primeira delas, a preocupação com a tradução enquanto área acadêmica. Por ser relativamente nova na Universidade - o curso da PUC-RJ, um dos mais antigos, foi iniciado com a reforma universitária de 1968 - a tradução constitui um campo importante e promissor, exigindo uma reflexão teórica sólida que considere todas aquelas áreas do saber de onde se podem extrair elementos relevantes para o seu estudo: a sociolinguística, a psicolinguística, a pragmática, a semântica, a teoria literária, a psicologia cognitiva, a filosofia, entre outras. Em segundo lugar, a relevância e a imprescindibilidade da tradução e do tradutor em um país linguisticamente isolado como o Brasil. Este fato precisa ser enfatizado, repetida e incessantemente, e cada tradutor deve tê-lo muito presente. E terceiro, a situação profissional do tradutor.

\footnotetext{
${ }^{1}$ N.E.: O II Encontro Nacional de Tradutores foi realizado nos dias 29 a 31 de maio de 1985 na PUC-Rio, sob a coordenação de Maria Candida Diaz Bordenave.
} 
Conhecemos muito bem a injustiça que se comete a cada dia com o tradutor, em termos do seu reconhecimento intelectual e da atribuição de honorários. Assim, estes três pontos, a tradução como área acadêmica, o seu papel social e o tradutor como profissional, foram os três eixos ao redor dos quais construímos o nosso programa, e ao redor dos quais esperamos unir os nossos esforços para atingir definições claras, fixação de diretrizes, programas de ação.

Em nome da comissão organizadora, quero expressar os nossos agradecimentos. Em primeiro lugar ao Professor Paulo Rónai, uma pessoa difícil de descrever com palavras, não só por seu trabalho como tradutor, mas também pela coordenação da Comédia humana, essa obra gigantesca que tanto honra a cultura nacional; por seus livros, Escola de tradutores e A tradução vivida, que o incluem entre os poucos tradutores que se detiveram a refletir sobre a tradução; e por sua presença marcante na causa do tradutor, como fundador da ABRATES, sempre defendendo a situação e a profissionalização do tradutor. Quero agradecer a Ivan Junqueira, que aceitou nosso convite para fazer uma palestra acerca da sua tradução de Eliot; ao acadêmico Antonio Houaiss, cuja presença expressa seu interesse pela área de tradução; a todos os participantes das mesas-redondas, que, com simpatia e até entusiasmo, aceitaram o nosso convite; à direção da PUC, através do padre Laércio, cuja presença aqui nos traz grande honra, dos Vice-Reitores e do Decano; à Diretora do Departamento de Letras, professora Mariza Pimenta-Bueno; e aos colegas do Departamento, que nesses três meses nos acompanharam com palavras de ânimo e apoio. Um agradecimento muito especial ao professor Silviano Santiago, a quem quero expressar nossa gratidão, pois, além de participar das mesas, foi durante todo o tempo o nosso assessor experiente e amigo. Agradeço às secretárias do Departamento de Letras, que além das suas ocupações cotidianas, já bastante grandes, aceitaram a incumbência de ajudar a montar este Encontro; à Coordenação dos Cursos de Extensão; à ABRATES, que colaborou eficientemente na divulgação entre os seus associados; e, last but not least, os agradecimentos calorosos ao Departamento de Programas Acadêmicos da IBM, na pessoa de seu diretor, José Paulo Schiffini, que se interessou pelo projeto e, ouvindo o clamor dos tradutores, nos forneceu apoio financeiro, tomando viável esta realização e possibilitando também a vinda do Sr. Lauro Grillo para a exposição sobre "A tradução na era da informática" Quero agradecer a presença de todos, e expressar os votos da comissão organizadora: que neste Encontro brote, no lugar do mote "tradutor, traidor", 
BORDENAVE - Apresentação do II Encontro Nacional de Tradutores

o mote "tradutor, recriador" não só do texto, mas de uma nova realidade para a tradução, de um novo tradutor, consciente de seu papel na história de nosso país. 